\title{
Pacificando o branco: uma história da MOdeRnidade CONTADA PELOS INDÍGENAS
}

\author{
Leno Francisco Danner ${ }^{1}$ \\ Fernando Danner ${ }^{2}$ \\ Julie Dorrico ${ }^{3}$
}

\begin{abstract}
Resumo: Apresenta-se, neste texto, a perspectiva de uma crítica da modernidade, por parte do pensamento indígena brasileiro, a partir da sua denúncia da modernização como movimento expansivo totalizante que tem, na imbricação de eurocentrismo-colonialismo-racismo e/como fascismo, seu núcleo estruturante e dinamizador. Defende-se a proposta de um pensamento-práxis indígena que oferece uma explicação alternativa da modernização, enquanto guerra de colonização calcada no racismo estrutural e tendo como consequência o etnocídio-genocídio planificado, o qual também propóe um papel epistêmico-político-normativo aos indígenas, por eles e desde suas formas de ser e estar no mundo, a saber, pacificar o branco. Com isso, inverte-se uma tripla lógica da modernidade: a modernidade como uma perspectiva endógena, autorreferencial e autossubsistente; a modernidade como movimento expansivo linear e reto, rumo ao universalismo pós-tradicional - e como universalismo pós-tradicional - via racionalidade cultural-comunicativa; e a modernidade como a condição exclusiva e necessária da crítica da modernização, da crítica do outro da modernidade e do sustento de uma noção universal de direitos humanos, os quais os outros da modernidade não conseguiriam gerar e nem sustentar.
\end{abstract}

Palavras-Chave: Pensamento Indígena. Descolonização. Modernidade. Colonialismo. Racismo.

${ }_{1}^{1}$ Professor de Teoria Política Contemporânea no Departamento de Filosofia e no Programa de PósGraduação em Filosofia da Universidade Federal de Rondônia (UNIR), Porto Velho, RO - Brasil.

C. https://orcid.org/0000-0002-2332-3182. E-mail: leno_danner@yahoo.com.br.

2 Professor de Ética e Filosofia Política no Departamento de Filosofia e no Programa de Pós-Graduação em Filosofia da Universidade Federal de Rondônia (UNIR), Porto Velho, RO - Brasil. $\mathrm{C}$ https:// orcid.org/0000-0003-2461-4819. E-mail: fernando.danner@gmail.com.

${ }^{3}$ Doutoranda em Teoria da Literatura pelo Programa de Pós-Graduação em Letras da Pontifícia Universidade Católica do Rio Grande do Sul (PUCRS), Porto Alves, RS - Brasil. https://orcid. org/0000-0002-5428-2432. E-mail: juliedorrico@gmail.com.

https://doi.org/10.1590/0101-3173.2022.v45esp.19.p379

This is an open-access article distributed under the terms of the Creative Commons Attribution License. 


\section{INTRODUÇÃo}

Apresentaremos, no texto, a crítica à modernidade formulada pelo pensamento indígena brasileiro, utilizando-nos também de elementos teórico-políticos desenvolvidos pela descolonização africana, em torno às lutas anticoloniais e à constituição de um lugar de fala como voz-práxis estético-política vinculada, carnal e militante, em face da condição e da causa negras ou, no nosso caso, indígenas. Nosso argumento central está em que o pensamento indígena brasileiro oferece uma história alternativa da modernidade-modernização ocidental, a saber, como guerra de colonização fundada no racismo estrutural e, correlatamente, assegura um papel propositivo importante aos indígenas, frente à modernidade, o qual consiste na pacificação do branco acerca de sua tendência eurocêntrico-colonialista-racista-fascista de instrumentalizaçáo e de etnocídio-genocídio dos não brancos.

Nesse sentido, o pensamento indígena brasileiro, assim como a descolonização africana, enfatiza a correlação de eurocentrismo-colonialismoracismo e/como fascismo, enquanto núcleo estruturante e dinamizador do movimento expansivo da modernidade-modernização europeia como sistemamundo global, assumindo, em consequência, uma crítica da modernidade enquanto práxis descolonizadora e descatequisadora, a qual rompe com cinco pressupostos constitutivos básicos do e para o paradigma normativo da modernidade, a saber: (a) a separação radical entre a modernidade europeia e os outros da modernidade, com a autonomização completa daquela em relação a estes; (b) a endogenia, a internalidade, a autorreferencialidade e a autossubsistência da modernidade enquanto correlação, separação e tensãocontradição de modernidade cultural e modernização econômico-social, com o consequente silenciamento sobre o - e apagamento do - colonialismo, como base e consequência dessa expansáo universalizante da modernidade; (c) a autoatribuição de universalidade da Europa e a sua tematização do outro da modernidade como condição pré-moderna, antimoderna e antimodernizante, com a consequente autoafirmaçáo dessa mesma Europa como positividade, presente, contemporaneidade e abertura para o futuro, como perspectiva autorreflexiva, autocorretiva e autotransformadora desde dentro, por si mesma e a partir de si mesma, consentânea à sua definição dos outros da modernidade como passado, dogmatismo, irreflexividade, negatividade e fanatismo, incapazes de gerar racionalização social e, portanto, incapazes de universalismo; (d) a estratificação hierárquica do gênero humano, em um processo evolutivo do qual a modernidade se assume como o presente, o 
árbitro, o juiz e o guia, seja do futuro desse gênero humano, seja da aderência ou não das demais sociedades-culturas-povos ao universalismo pós-tradicional; e (e) a afirmação de que a crítica da modernidade, a crítica dos outros da modernidade e a fundação do universalismo epistemológico-moral somente são possíveis pela modernidade, na modernidade e como modernização, isto é, como desnaturalização, politizaçâo e descentração da sociedade-culturaconsciência e em termos de procedimentalismo imparcial, impessoal, neutro e formal.

Ora, por meio da tríade eurocentrismo-colonialismo-racismo e/como fascismo, o pensamento indígena brasileiro - assim como a descolonização africana - explicita a cegueira histórico-sociológica, o dualismo-binarismo antropológico e a romantizaçáo normativa do racionalismo ocidental, ou seja, educa, reflexiviza e enquadra criticamente à modernidade, em seu déficit de reflexividade, de autocrítica e de universalidade. Nesse caso, portanto, o outro da modernidade, produzido por essa mesma modernidade como negatividade, esclarece-a relativamente ao Esclarecimento, inclusive apresentando perspectivas paradigmáticas alternativas (por exemplo, o xamanismo), trazendo histórias, experiências e valores alternativos (formas de socialização comunitárias, decrescimento econômico e sustentabilidade ecológica, ancestralidade e espiritualidade) e apontando, em última instância, para uma nova base ao universalismo não etnocêntrico e não egocêntrico, a Mãe Terra ou Pachamama.

Gostaríamos, por fim, de esclarecer três pontos de partida que estamos utilizando, no texto, como eixo estruturante dessa perspectiva de constituição e de desenvolvimento de um pensamento indígena brasileiro, enquanto uma voz-práxis pan-indígena de crítica à modernizaçáo periférica e conservadora brasileira, em particular, e de enquadramento da modernidade-modernizaçáo ocidental, de um modo mais geral, a qual assume concomitantemente a postura de uma pluralizaçáo de pertenças étnicas, com todos os protagonistas e todas as produçôes teórico-práticas consequentes.

Os três pontos são: primeiramente, a fundaçáo do Movimento Indígena brasileiro, a partir de meados da década de 1970, levando a seus desdobramentos, ao longo das décadas seguintes, com o surgimento de lideranças e de intelectuais indígenas que se consolidam na esfera pública, política e cultural, a partir dele, em nome dele; o segundo diz respeito a uma reestilização do conceito de "índio" ou de indígena, sob a forma de crítica ao indio genérico, o qual passa, com o Movimento Indígena, a ser compreendido 
e afirmado enquanto poder originário da diferença como positividade, sendo colocado pelo Movimento Indígena e seus intelectuais como o ponto de partida para uma perspectiva de descolonização e de descatequização de nossa sociedade - e desde o qual assumem exatamente sua especificidade e sua pungência, em termos de lugar de fala; e, em terceiro lugar, um breve esclarecimento do significado dos termos "xamanismo" e "xamä", tal como os estamos utilizando aqui, para definir a perspectiva xamânica indígena, de uma forma geral e, em especial, a posição yanomami sustentada por Davi Kopenawa, citado neste texto.

O Movimento Indígena brasileiro, surgido a partir de 1974, foi constituído inicialmente por certas lideranças indígenas, como Álvaro Tukano, Ailton Krenak, Mário Juruna, Celestino Xavante, Samado Pataxó, Nelson Xangrê Kaigang, Carlos Estevão Taukane, Cipassé Xavante, Davi Kopenawa, Marcos Terena, Idjarruri Karajá, Paulinho Borôro, Domingos Veríssimo Terena, Lino Miranha e Daniel Kabixi etc. Nesse momento, havia uma tripla intenção enquanto fundamento da constituição do Movimento Indígena: (a) consolidar uma perspectiva de autonomia e de autodeterminaçáo indígenas, diante do controle realizado pela Ditadura Militar, desde a FUNAI, contra os povos indígenas, buscando resistir aos processos de integraçáo promovidos pelos governos militares (os quais levavam à perda das identidades indígenas) e, principalmente, ao seu estímulo à expansão agrícola no Centro-Oeste e no Norte do país, situação que, no dizer de Ailton Krenak, ameaçava seriamente a existência dos povos indígenas brasileiros daquelas regióes - como ele nos diz, no que se refere a essa perspectiva de resistência às políticas integracionistas e à expansão agrícola promovidas pela Ditadura Militar: "Naquela época, o futuro era, no máximo, o ano seguinte.” (MUNDURUKU, 2012, p. 82) 4 $^{4}$ (b) o enraizamento e a militância na esfera pública, política e cultural, de modo que os próprios povos indígenas pudessem se dar a conhecer e, por meio de suas organizaçóes e lideranças, dialogar com a sociedade envolvente, tornandose os reais interlocutores da condição e da causa indígenas no país, superando a tutela tecnocrática e a maioridade relativa às quais estavam submetidos pelo Estado brasileiro (e que somente foi derrogada com a Constituição Federal de 1988, no Capítulo dos Índios) - conforme assevera Álvaro Tukano: "Se

\footnotetext{
${ }^{4}$ E ele complementa: "As pessoas se perguntam o que tanta gente diferente que se encontrou naquele momento, índios de diversas etnias, ribeirinhos, seringueiros, podiam ter em comum. O que tinham em comum era o medo do progresso! No nosso caso, muito mais do que isso, era o medo do branco. Mas não de um branco qualquer. Existe todo um esquema, um acúmulo de capital.. O índio achou que não sobreviveria a isso." (KRENAK, 2015, p. 220).
} 
a tutela fosse uma salvação de fato, eu bateria palmas. Mas tem limitado a minha voz, tem atado as minhas mãos. [...] o público tem de ouvir diretamente o que os verdadeiros líderes pensam, falam e defendem sobre a questão indígena." (TUKANO, 2017); e (c) a busca pela consolidação de processos formativos que garantissem, seja a inserção social dos sujeitos indígenas, seja a preparação de quadros de lideranças que dariam continuidade à luta indígena, inclusive apontando para a necessidade de transformaçóes institucionais que efetivamente viabilizassem a existência dos povos indígenas brasileiros. Esta é a primeira fase, por assim dizer, da constituição do Movimento Indígena brasileiro e de definição dos eixos de sua militância institucional e sociopolítica.

Como consequência desse protagonismo inicial, tem-se, a partir da década de 1980, uma, por assim dizer, segunda fase do Movimento Indígena brasileiro enquanto perspectiva pan-indígena, a qual assume um duplo embora interligado - aspecto: (a) a constituição de diversas organizaçóes indígenas, as quais, tanto nos seus lugares de origem e nas suas regióes de abordagem quanto, inclusive, no âmbito federal (e sempre interseccionadas e em mútuo suporte), buscavam pluralizar a resistência e o diálogo indígenas com as instituiçóes e a sociedade envolvente - é dessa época que emergem a União das Naçóes Indígenas (UNIR), em 1982, a Coordenadoria de las Organizaciones Indígenas de la Cuenca Amazónica (COICA), em 1984, a Federação das Organizaçôes Indígenas do Rio Negro (FOIRN), também em 1984, e a Coordenação das Organizaçóes Indígenas da Amazônia Brasileira (COIAB), em 1989; e (b) a defesa, seja do acesso dos povos indígenas à educação formal e aos direitos cidadãos básicos, principalmente em termos de superação da tutela tecnocrática e da maioridade relativa e de afirmação do direito de autodeterminaçáo cultural e territorial, bem como da consolidação da demarcação das terras indígenas e da regulação da propriedade intelectual dos seus saberes, tradiçóes e produtos - é na década de 1980 que temos a consolidação na Constituição Federal do Capitulo dos Índios (artigos 231 e 232), que versa sobre o direito originário à terra, à organização social, aos costumes, às línguas, às crenças e às tradiçóes próprias, e que concede aos sujeitos indígenas (coletiva e individualmente) o status de sujeitos jurídicos na plenitude de suas capacidades (eliminando, portanto, a maioridade relativa vigente desde 1910. com o Estatuto do Índio), e é dessa época que emerge seja a educação escolar indígena diferenciada (1988), seja as demarcaçóes de terras (1992), seja, finalmente, das medidas institucionais e legais de proteção da propriedade intelectual indígena e de combate à biopirataria (1996). Dessa segunda fase, poderíamos acrescentar, àquelas lideranças acima elencadas, 
Eliane Potiguara, Gersem Baniwa, Darlene Yaminalo Taukane, Biraci Yawanawá etc.

Finalmente, temos isso que poderíamos chamar genericamente de um terceiro momento próprio ao desenvolvimento do Movimento Indígena brasileiro, caudatário exatamente da consolidação da educação escolar indígena e do acesso à formação universitária, por parte dos sujeitos indígenas. A formação escolar, técnica e universitária permitiu o acesso deles, em diversos setores da sociedade, quer nas instituiçôes públicas, quer na esfera econômica, quer, finalmente, na esfera pública, política e cultural, inclusive em termos de domínio, utilização e crítica de epistemes propriamente ocidentais ou euronorcêntricas.

Para o que nos interessa aqui, é com essa terceira fase que se consolidam e se amplificam as produçóes teóricas indígenas, especialmente, para o nosso caso, nesse texto, a literatura indígena brasileira, a qual se ramifica em (a) produçôes didático-pedagógicas direcionadas aos povos indígenas aldeados e oriundas dessa necessidade de uma educação escolar indígena bilíngue literatura indígena de autoria coletiva; (b) produçóes literárias de vários estilos (contos, poemas, crônicas, ensaios, romances, autobiografias etc.), as quais denominamos literatura indígena brasileira contemporânea como autoria individual; (c) a publicação e a disponibilização, tanto para uso entre os sujeitos e coletivos indígenas quanto para a divulgação à sociedade civil, de um modo mais geral, das ontologias indígenas (Antes o mundo não existia, por Tolāman Kenhíri e Umúsin Panlōn Kumu; $O$ mundo tukano antes dos brancos, de Álvaro Tukano; $O$ trováo e o vento: um caminho de evolução pelo xamanismo tupi-guarani, de Kaká Werá; A queda do céu: palavras de um xamã yanomami, de Davi Kopenawa e Bruce Albert; A terra é uma só, de Timóteo Verá Tupã Popygua); e (d) a produção científica acadêmica, nas diversas áreas das ciências humanas e sociais, por parte dos próprios intelectuais indígenas inseridos nas instituiçôes de ensino e de pesquisa (Gersem Baniwa é um dos exemplos, o qual, aliás, perpassa essas três fases do Movimento Indígena brasileiro) - essa fase culmina, por exemplo, seja na divulgação da Carta kari-oca, de 30 de maio de 1992, como manifesto político-intelectual indígena no qual se reiteram o direito à autodeterminação e à identidade cultural e o direito inalienável à terra e aos recursos naturais, inclusive com sua transmissão como direito às geraçóes indígenas futuras (TERENA, 1992, p. 31), seja a carta publicada no I Encontro Nacional de Escritores Indígenas, em 2004, em que se defendia tanto o caráter coletivo e tradicional dos conhecimentos indígenas, que não 
podiam ser compreendidos como domínio público, sendo pertencentes apenas aos povos indígenas, quanto a ideia de que a produçáo de livros de autoria indígena seria vista como um caminho para revigorar-se as tradiçóes e os valores indígenas, por meio da edição e da difusão desses mesmos livros de autoria indigena, apontando-se, portanto, para a necessidade de desenvolver-se a autoria indígena como voz-práxis direta, vinculada e política-politizante, com o que, inclusive, a sociedade poderia dialogar diretamente com as lideranças e os intelectuais indígenas, sem mediaçóes tecnocráticas (MUNDURUKU, 2006, p. 2002).

Desse terceiro momento, poderíamos destacar, juntamente com as lideranças e intelectuais precedentes, Daniel Munduruku, Kaká Werá, Tonico Benites, Olívio Jekupé, Jozileia Daniza Kaigang, Eloy Terena, Sonia Guajajara, Jaider Esbell, Edson Krenak, Edson Kayapó, Márcia Mura, Rita Potiguara, Graça Graúna, Julie Dorrico etc.

Note-se, portanto, a ampla miríade de lideranças e de intelectuais indígenas que se desenvolvem em termos de Movimento Indígena brasileiro e desde a intersecção e a dinamização de seus diferentes momentos constitutivos. Correlacionando militância e produção teórica, eles/as se inserem de diferentes maneiras, nessa dinâmica, que desenvolvemos acima, assumida pelo Movimento Indígena brasileiro, ao longo de seus quase cinquenta anos de existência - inclusive, nesse sentido, a vinculação desses/as intelectuais indígenas ao Movimento Indígena se dá não apenas através do ativismo político, mas também estético, literário, científico, cultural, pedagógico etc. (o que significa que nenhum/a deles/as está mais ou menos vinculado/a ao Movimento Indígena por ser respectivamente mais ou menos ativista, assim como, em consequência, que nenhum/a deles/as é mais ou menos indígena, por estar na linha de frente em termos de militância política ou náo).

Também é importante lembrar que nem todas essas lideranças deixaram documentos escritos, o que impede o nosso acesso direto a suas posiçôes teórico-políticas. De todo modo, neste texto, escolhemos algumas dessas lideranças que assumem também o papel de intelectuais da questáo e da causa indígenas no país e que, por isso mesmo, nos legaram uma produção literária exuberante e pujante, no que se refere à crítica da modernidade, a qual ainda não foi ainda estudada e assimilada consistentemente por nossa comunidade filosófica, com uma intensidade pelo menos aproximada àquela com que se valorizam os textos de teorias e de autores/as euronorcêntricos/as. 
Ademais, tanto a atuação do Movimento Indígena brasileiro quanto essa constituição de um pensamento indígena brasileiro como movimento epistêmico-político-normativo, daquele caudatária, permitem, seja a constituição de uma voz-práxis pan-indígena, seja a pluralização das ontologias, das formas de ser e estar no mundo próprias aos diferentes povos indígenas - assim é que, nesse último caso, temos a literatura indígena maraguá (Yaguarê Yamã e Roni Wasiri Guará etc.), a literatura indígena potiguara (Eliane Potiguara e Graça Graúna etc.), a literatura indígena guarani (Olívio Jekupé, Kaká Werá, Maria Lúcia Takua etc.), a literatura indígena munduruku (Daniel Munduruku, Ytanajé Coelho Cardoso, Marcelo Munduruku etc.), a literatura indígena Krenak (Ailton Krenak, Edson Krenak, Shirley Krenak etc.), entre outras.

A pluralização de ontologias e de perspectivas estético-literárias próprias aos diferentes povos indígenas é um dos eixos estruturantes da constituição e do desenvolvimento de um pensamento indígena brasileiro. Entretanto, neste texto, nós daremos ênfase à ideia de uma voz-práxis pan-indígena enquanto definidora do pensamento indigena brasileiro, uma vez que ela é consequente à intenção fundadora e dinamizadora do Movimento Indígena brasileiro de politização e de resgate do conceito de "índio", como inclusive desenvolveremos, ao longo do artigo. No caso, portanto, se a literatura romântica e indianista, em particular, e o racismo estrutural ínsito à sociedade brasileira, de um modo mais geral, produziram o indio genérico e ossificado no passado como condição pré-moderna, antimoderna e antimodernizante, mero corpo, instinto e animalidade, ora bárbaro, ora papel em branco - por conseguinte, se a herança colonial é exatamente o "índio" como negatividade, como menoridade -, o Movimento Indígena brasileiro e o pensamento indígena dali emergente (e como legitimação normativa daquele) assumem plenamente o sentido político-normativo ínsito a ele e exatamente sob a forma de crítica da tríade eurocentrismo-colonialismo-racismo e/como fascismo. Enquanto um bloco teórico-político, a voz-práxis pan-indígena aponta para a reestilização e a ressignificação do termo indio ou indígena e, nesse caso, para sua transformação em, parafraseando Achille Mbembe, poder originário da diferença, descentraçáo discursiva e positividade político-normativa (MUNDURUKU, 2012, p. 220-222).

Finalmente, em último lugar, um breve esclarecimento acerca do sentido do termo xamanismo/xamã, utilizado neste texto para significar as ontologias indígenas e, de modo muito específico, para definir a postura do 
líder indígena yanomami Davi Kopenawa, particularmente no seu maravilhoso A queda do céu: palavras de um xamã yanomami. Nesse caso, empregamos xamanismo/xamã como tradução do termo yanomami xapiri the $p \ddot{e}$, o qual designa o conceito de xamã(s), significando gente espirito; as "pessoas comuns", ao contrário, são chamadas de kuapora thë pë, isto é, gente que simplesmente existe. Enquanto estas últimas veem apenas a aparência do mundo, dos seres e dos fenômenos, aquelas conseguem acessar a imagem-essência desse mesmo mundo, dos seus seres e dos seus fenômenos. Por isso, nesse sentido, Davi Kopenawa, como xamã yanomami, se coloca como um interlocutor entre dois mundos, o mundo yanomami e o mundo ocidental, falando em nome de seu povo e em termos da condição e da causa indígenas.

O xamanismo/xamã, tal como o estamos usando aqui, tem seu sentido exatamente nessa perspectiva de imbricação entre natureza, cultura e subjetividade e, portanto, na ideia de que estamos perpassados por espiritualidade ou, melhor dito, de que fazemos parte, todos/as, de Pachamama (embora esta varie de povo para povo, nunca é entendida como mera res extensa, servindo, assim, tanto como crítica à modernidade-modernizaçáo ocidental quanto como base de um universalismo horizontalizado, não etnocêntrico e não egocêntrico). Nesse sentido, o xamanismo/xamã é o correlato, por exemplo, da ciência e do cientista modernos, na medida em que estes têm seu sentido em termos de centralidade epistêmico-normativa caudatária da separação entre natureza, cultura e subjetividade própria ao fenômeno da europeização. Importante salientar, com isso, que estamos adotando esses termos de modo positivo, ao contrário, conforme mostraremos ao longo do texto, do discurso filosófico-sociológico-antropológico da modernidademodernizaçáo europeia, que os concebe como negatividade, como passado antropológico, como condição fundamentalista e dogmática, com sentido e orientação antimodernos e antimodernizantes, irreflexivos, acríticos e incapazes de racionalização.

1 A base dualista-binarista do discurso filosófico-sociológico da MODERNIDADE, O APAGAMENTO DO COLONIALISMO E O NÁO LUGAR DOS INDÍGENAS (E NEGROS)

A constituição de um discurso filosófico-sociológico da modernidade europeia tem sua dinâmica central no espanto e na consequente interrogação, que, nas palavras de Max Weber, o sujeito europeu sente em relação ao fato de 
que sua estrutura societal-cultural-consciencial, quando comparada a todas as outras formas de sociedade-cultura-consciência, apresenta um sentido e uma vocação universalistas, ao mesmo tempo que historicistas, via racionalização social. Assim, o sujeito europeu, que quer reconstruir e entender o lugar, o sentido e o caminho da modernidade-modernização ocidental como europeização internamente e, por óbvio, já que ela é universalista, no amplo contexto e escopo do desenvolvimento do gênero humano, de um modo geral, parte do pressuposto (a) de que sua civilização-cultura-consciência é singular relativamente a todas as outras formas de sociedade-cultura-consciência; (b) de que há um nível moderno, próprio à Europa e como Europa, e um nível pré-moderno, enquanto tradicionalismo em geral, o qual subsume todas as outras sociedades-culturas-consciências; e, finalmente, (c) de que a sociedadecultura-consciência moderna ou europeia é universalista e/porque historicista, devido à racionalização social, não necessitando, para instaurar, justificar e realizar esse mesmo universalismo, de nenhuma perspectiva essencialista e naturalizada, como, ao contrário, o faz o tradicionalismo em geral.

Nessa perspectiva, com Max Weber, dá-se a tônica e se estabelecem os pressupostos e as bases disso que Jürgen Habermas chamará, logo depois, de discurso filosófico-sociológico da modernidade, enquanto universalismo póstradicional ou pós-metafísico calcado na racionalidade cultural-comunicativa. Destaca Weber (1984, p. 11, grifos nossos):

O filho da moderna civilização ocidental, que trata de problemas históricouniversais, o faz de modo inevitável e lógico a partir da seguinte dinâmica: que encadeamento de circunstâncias possibilitou que aparecessem no Ocidente, e somente no Ocidente, fenômenos culturais (pelo menos como os representamos a nós) que apresentam uma dirȩ̧ão evolutiva de alcance $e$ de validade universais?

A essa pergunta, Habermas procura dar uma resposta dupla, de sorte a evidenciar-se, primeiramente, a separação e a não mutualidade entre modernidade europeia e o outro da modernidade, com a correlata independência recíproca e, por conseguinte, a ideia de um purismo, de uma autonomia, de uma internalidade e de uma endogenia fortes da Europa, enquanto - e esse seria o segundo ponto - um processo constitutivo-evolutivo autorreferencial e autossubsistente, que emerge e se desenvolve e pode ser explicado exclusivamente por fatores internos. No primeiro caso, portanto, Habermas retoma essa pressuposição de uma condição totalmente singular 
da Europa como modernização ou da modernidade como europeização, a qual se diferencia estruturalmente dos outros da modernidade; no segundo, a explicação da constituição, do desenvolvimento e da evolução da modernidade, que é endógena, autorreferencial e autossubsistente, centra-se na correlação, na separação e na tensão-contradição entre modernidade cultural e modernização econômico-social, o que tem como consequência o apagamento do e o silenciamento sobre o colonialismo, como momento constitutivo e consequência da modernidade-modernizaçáo ocidental (e justificado pela modernidade cultural!).

Quanto ao ponto de partida da resposta - já pressuposta - acerca da universalidade da Europa e a profunda contextualização-particularização dos outros da modernidade, Habermas usa o dualismo-binarismo como a base justificadora de seu discurso filosófico-sociológico. Ele enfatiza:

À medida que procuramos aclarar o conceito de racionalidade com base no uso da expressão "racional", tivemos de nos apoiar sobre uma précompreensão que se encontra ancorada em posicionamentos modernos da consciência. Até o momento, partimos do pressuposto ingênuo de que na compreensão de mundo moderna expressam-se certas estruturas da consciência que pertencem a um mundo da vida racionalizado e por princípio possibilitam uma conduçáo racional da vida. Implicitamente, relacionamos à nossa compreensão de mundo ocidental uma pretensáo de universalidade. Para entender o significado dessa pretensáo de universalidade, recomenda-se fazer uma comparação com a compreensão de mundo mítica. Em sociedades arcaicas, os mitos cumprem de maneira exemplar a função unificadora própria às imagens de mundo. Ao mesmo tempo, no âmbito das tradiçóes culturais a que temos acesso, eles proporcionam o maior contraste em relação à compreensão de mundo dominante em sociedades modernas. Imagens de mundo míticas estáo muito longe de nos possibilitar orientaçôes racionais para a ação, no sentido em que as entendemos. No que diz respeito às condiçóes da condução racional da vida no sentido anteriormente apontado, constituem até mesmo uma contraposição à compreensáo de mundo moderna. Portanto, na face do pensamento mitico não teriam de se fazer visiveis os pressupostos do pensamento moderno tematizados até o momento. (HABERMAS, 2012a, p. 94, grifos nossos).

O que Habermas está dizendo, assim como Weber já o havia feito (e, não por acaso, Weber é a referência constante de Habermas), é que o discurso filosófico-sociológico da modernidade-modernizaçáo europeia quer justificar essa pressuposição de que a Europa é universal por causa da racionalização 
cultural, e que fará isso, enquanto seu ponto de partida, seja a partir da completa diferenciação e independência da modernidade em relação aos outros da modernidade, seja por meio da análise comparativa entre a estrutura societal-cultural-cognitiva moderna e a estrutura societal-cultural-cognitiva mítica ou arcaica ou tradicional (termos utilizados com o mesmo sentido, em Habermas e, depois, em Axel Honneth).

De antemão, como já vimos, assume-se a superioridade da modernização em relação ao tradicionalismo e, em particular, concebem-se as sociedades mítico-arcaicas como incapazes de racionalização interna e, pois, conforme veremos adiante, como incapazes de desnaturalização e politização da sociedade-cultura-consciência, ao contrário da modernidade, que é, por causa da racionalização, uma sociedade-cultura-consciência altamente desnaturalizada, historicizada e politizada; como consequência, sociedadesculturas-consciências mítico-arcaicas não são universais, mas particulares e contextualistas, ao passo que a modernidade europeia é universalista, em termos pós-tradicionais, isto é, desde uma perspectiva não etnocêntrica e não egocêntrica dinamizada como procedimentalismo imparcial, impessoal, neutro e formal.

No ponto de partida da constituição e da legitimação do discurso filosófico-sociológico da modernidade, por conseguinte, encontramos (a) uma separação absoluta entre modernidade e o outro da modernidade, bem como, em consequência, (b) a exclusão desse outro da modernidade, enquanto fator explicativo do universalismo "pós-tradicional" (e somente haveria universalismo efetivo, se fosse pós-tradicional, enquanto pós-tradicional), o qual esse outro não é, não tem, não gera e nem consegue acessar - ademais, esse outro é um contexto-sujeito genérico que, no conceito de sociedades míticoarcaicas ou de tradicionalismo em geral, ensaca de modo simplificador à ampla miríade de culturas e de povos não europeus, sem qualquer atenção específica e abrindo mão de qualquer diferenciação séria. A modernidade europeia passa, com isso, a ser entendida como presente e contemporaneidade, como autoconsciência, autorreflexividade e autotransformaçáo enquanto presente e contemporaneidade e, por isso mesmo, totalmente aberta ao futuro, o qual ela mesma constrói (cf. HABERMAS, 2002a, p. 03-122).

O outro da modernidade, em contrapartida, como condição-sujeitovalor pré-moderno (e antimoderno e antimodernizante), está situado no passado e possui uma condição deficitária - porque dogmática, fanática, absolutista - em termos de justificação da objetividade epistemológico-moral 
e de enquadramento da alteridade, a qual, por não ser universalista, ele não consegue ver, entender e reconhecer. Com isso, depois de ter escanteado aos outros da modernidade em termos de inteligibilidade interna ao e pelo discurso filosófico-sociológico da modernidade, concebendo-o exclusivamente como dinâmica-princípio endógeno, autorreferencial e autossubsistente da Europa por si mesma e desde dentro de si mesma, Habermas pode recorrer à correlaçáo de racionalidade cultural-comunicativa e racionalidade instrumental, ou modernidade cultural e modernização econômico-social (capitalismo e Estado burocrático-administrativo), a fim de entender o sentido, o movimento e o caminho dessa mesma modernidade-modernização ocidental. Ele assinala, relativamente a essa noção endógena, autorreferencial e autossubsistente de modernizaçáo como europeização:

(p) $\mathrm{O}$ desenvolvimento das sociedades modernas, que são acima de tudo capitalistas, exige a incorporaçáo institucional e a ancoragem motivacional de ideias morais e jurídicas de tipo pós-tradicional;

(q) Além disso, a modernização capitalista segue um padrão segundo o qual a racionalidade cognitivo-instrumental não se limita às esferas da economia e do Estado, alastrando-se para outros domínios da vida, estruturados comunicativamente, em que consegue obter a primazia à custa da racionalidade prático-moral e prático-estética;

(r) Esse fator provoca perturbaçóes na esfera da reproduçáo simbólica do mundo da vida. (HABERMAS, 2012b, p. 551).

Enquanto um processo endógeno, autorreferencial e autossubsistente, a modernidade-modernização ocidental é definida, compreendida e dinamizada como correlação, separação e tensão-contradição entre cultura e civilização material, racionalidade comunicativa e racionalidade instrumental, modernidade cultural e modernização econômico-social. E o colonialismo? Nenhuma palavra, nenhuma menção, silêncio completo. Assim, ficamos com a sensaçáo de que ou ele é um acidente de percurso da modernidade, não sua intenção e nem sua responsabilidade, em sentido estrito, ou talvez ele se reduza ao instrumentalismo econômico; todavia, se a segunda hipótese for verdadeira (uma vez que a afirmação da primeira seria muita hipocrisia e cegueira teórico-política), ela não explicaria nada sobre a base normativa desse mesmo colonialismo, a saber, o racismo estrutural (o qual tem de ser explicado moral, política e cientificamente), e sequer apresentaria os impactos do eurocentrismo-colonialismo-racismo, tanto como expansão totalitária da modernidade frente aos outros da modernidade (que, por isso mesmo, 
são construídos nesse processo) e em termos de justificação normativa de menoridades político-culturais racialmente estruturadas quanto no que tange à própria (de)formação da cultura e do sujeito europeus - a descolonização africana insistirá, no que diz respeito a isso, no fato de que o eurocentrismocolonialismo-racismo é a experiência primigênia e mais fundamental de fascismo planificado como etnocídio-genocídio (calcado no racismo estrutural) e, depois, como consequência, enquanto regressão totalizante e autodestrutiva interna, da Europa em relaçáo aos outros da modernidade, da Europa contra si mesma.

Em suma, o discurso filosófico-sociológico da modernidade se constitui a partir de uma cadeia problemática de pressuposições teóricopolíticas: (a) a separaçáo e a independência radicais entre modernidade (como presente, contemporaneidade e abertura ao futuro) e o outro da modernidade, como condição-sujeito pré-moderno, antimoderno e antimodernizante; (b) a correlação de modernidade, racionalização e/como universalismo pós-tradicional, pós-convencional ou pós-metafísico, e de outro da modernidade como tradicionalismo, perspectiva mítico-arcaica particularista e contextualizada, não racional e incapaz de racionalização; (c) endogenia, autossubsistência e autorreferencialidade do processo de modernidademodernização ocidental como correlação, separação e tensão-contradição entre modernidade cultural e modernização econômico-social, racionalidade cultural-comunicativa e racionalidade instrumental; e, como consequência, (d) apagamento do e silenciamento sobre o colonialismo-racismo enquanto princípio constitutivo, dinâmica e caminho evolutivo dessa mesma modernidade-modernização ocidental, calcado, aliás, no racismo estrutural.

\section{MODERNIDADE EUROPEIA COMO REFLEXIVIDADE-POLITICIDADE, OUTRO DA} MODERNIDADE COMO DOGMATISMO-APOLITICIDADE

Conforme estamos argumentando, os indígenas e os negros - enquanto essa sopa indiferenciada, como tradicionalismo em geral e perspectiva míticoarcaica, como pré-modernidade - aparecem como pressuposto inicial do e pelo discurso filosófico-sociológico da modernidade, mas exatamente sob a forma de negatividade, de déficit, de passado, o qual serve, portanto, como antonomásia para justificar exatamente o caráter especial e esse movimento endógeno e essa separaçáo absolutos da modernidade em relação ao outro da modernidade. 
Com efeito, para Habermas, sociedades mítico-arcaicas não são racionais e nem geram racionalização social, conforme vimos em passagem dele acima, porque são marcadas pela férrea imbricação de natureza ou mundo objetivo, sociedade-cultura e subjetividade, e isso de um modo especial: a natureza é compreendida em termos antropomórficos; a sociedade é naturalizada e, portanto, despolitizada; e não existe subjetividade em sentido estrito, nessas sociedades mítico-arcaicas, uma vez que os indivíduos estão subsumidos em um mundo mágico-animista e dogmático-fundamentalista-fanaticista que não permite nem a instrumentalização da natureza, nem a politização da sociedade e nem o protagonismo do sujeito reflexivo. Enquanto sociedadesculturas-consciências míticas, elas apresentam uma estrutura totalizante, unidimensional e massificada, a qual impede a reflexividade individual, a crítica e a mobilidade sociais e a transformação sociopolítica, tornando-as dependentes da magia (e não da ação humana) como critério explicativolegitimador, imobilizando-as socialmente (por causa da naturalização das posiçôes político-institucionais) e menorizando-as política e moralmente.

Ao contrário, a sociedade-cultura-consciência europeia como modernidade-modernização possui como seu cerne a racionalização culturalcomunicativa, a qual permite exatamente a separação entre natureza, sociedadecultura e consciência cognitivo-moral, de modo a se instrumentalizar a natureza, a se desnaturalizar e politizar a sociedade-cultura e a se atribuir todo o protagonismo à subjetividade reflexiva. Daqui emerge o universalismo epistemológico-moral pós-tradicional, necessário a uma sociedade pluralizada, secularizada e profana, que não pode mais recorrer a fundamentos essencialistas e naturalizados como base de sua autolegitimidade interna.

Os sujeitos sociais teráo de interagir entre si, com vistas à construção dessa mesma objetividade vinculante e, para isso, deveráo gradativamente utilizar-se de argumentos formais e de uma perspectiva axiológicometodológica imparcial, impessoal e neutra, os quais são independentes de posiçôes pré-políticas, pré-culturais e a-históricas, calcadas única, exclusiva e suficientemente, em uma ideia genérica e universal de ser humano ou humanidade (direitos humanos, sujeito jurídico como detentor de direitos fundamentais, isonomia jurídico-político-moral etc.). Forma-se um universalismo não etnocêntrico e não egocêntrico, calcado exclusivamente na universalidade dos direitos humanos e tendo a democracia como sua base político-procedimental garantidora da objetividade normativa, por meio da disputa, do consenso e do acordo recíproco. 
Para Habermas, é esse processo de descentração da concepção do mundo, viabilizado e pungenciado pela racionalização cultural-comunicativa, que efetivamente se constitui no umbral civilizacional que singulariza, diferencia e coloca a modernidade-modernização europeia como a base desde a qual o nível pós-tradicional da consciência moral emerge pela primeira vez, na história do gênero humano - é pela modernidade e como modernização que o universalismo pós-tradicional é instaurado, e por ninguém mais (HABERMAS, 2012a, p. 384-385, p. 683; HABERMAS, 2002b, p. 07-08); por outro lado, esse mesmo umbral significa, mais uma vez, não só o reforço da endogenia, da autorreferencialidade e da autossubsistência da modernidade por si mesma e desde si mesma, mas também, seja a normalização da exclusão dos outros da modernidade enquanto parte constitutiva da modernização (e como produto dela sob a forma do colonialismo-racismo), seja a estabilização de uma hierarquia evolutiva ao gênero humano que coloca a modernidade como europeizaçáo enquanto o presente, a contemporaneidade e, assim, o direcionamento para o futuro desse mesmo gênero humano (e, por isso mesmo, como o guia e o caminho dele), concomitantemente a situar os outros da modernidade no passado e como caminho-condição-sujeito superado, os quais, ou se atualizam (como modernizaçáo-europeizaçáo), ou se extinguem.

O importante dessa ideia não reside apenas na estratificação e na hierarquização da evolução do gênero humano, em geral, que tem os outros da modernidade como passado, a modernidade europeia como presente e contemporaneidade e direcionamento ao futuro, mas também o pressuposto de que somente pode haver justificação, reflexividade, crítica e transformação social na, como e pela modernidade, pois somente ela, pela correlação de racionalização, desnaturalização e politizaçáo, se viabiliza como perspectiva societal-cultural-cognitiva antitotalitária, antifascista, não fundamentalista e antirracista, a qual exige a interatividade política democrática calcada na reciprocidade, na isonomia e na universalidade dos direitos fundamentais, como base da justificação da normatividade social. Como frisa Habermas, "[...] a descentração da compreensão de mundo e a racionalização do mundo da vida são condiçóes necessárias para uma sociedade emancipada." (HABERMAS, 2012a, p. 146, grifos nossos).

Note-se, entretanto, que essa concepção inflada, que, ao mesmo tempo, exclui o outro da modernidade, em termos de este ser capaz de autojustificação interna reflexiva e de concomitante crítica da modernidade, bem como centraliza na modernidade todo o protagonismo, em termos de 
crítica, reflexividade, intervenção e transformação em torno ao universalismo pós-tradicional, somente pode ser sustentada pela cegueira históricosociológica, pelo dualismo-binarismo antropológico e, finalmente, pela romantização normativa do racionalismo ocidental, que são viabilizadas pela separaçáa absoluta e pelo purismo estrito da modernidade em relação aos outros da modernidade, pela endogenia, pela autorreferencialidade e pela autossubsistência da modernidade-modernização por si mesma e desde si mesma e, finalmente, pela produção desse outro da modernidade, como negatividade e passado, com a consequente pressuposição da modernidade por si mesma e desde si mesma, como positividade, presente, contemporaneidade e futuro do gênero humano - de modo que é o silenciamento sobre o e o apagamento do colonialismo que precisam ser assumidos, para que a modernidade cultural possa manter-se como estrutura societal-cultural autorreflexiva, autocorretiva e autotransformadora.

Axel Honneth, na sua justificação da existência de uma lógica universal do reconhecimento, enquanto núcleo constitutivo e dinamizador do e pelo gênero humano, em geral, e de cada sociedade-cultura-consciência, em particular, parte dessa afirmação habermasiana de que apenas a estrutura societal-cultural-cognitiva pós-tradicional, por causa da desnaturalizaçáo, da politização e da diferenciação sociais, consegue garantir justificação, reflexividade, crítica e transformação. $\mathrm{E}$, mais uma vez, ele tem de recorrer a uma noção negativa de outro da modernidade, como moral arcaica de grupo, para dar a legitimação básica a esse caráter evolutivamente superior da modernidade-modernização, enquanto universalismo pós-tradicional.

Para provar que a dinâmica tripartite de uma luta por reconhecimento é o estágio atual ou contemporâneo do processo de evolução humana como universalismo pós-tradicional, por meio da diferenciação e da mutualidade das esferas da família, do direito e da socialização política, processo tripartite esse cuja conclusão bem-sucedida é a única forma de os sujeitos adquirem autoconfiança, autorrespeito e autoestima (e, inclusive, de se individuarem de modo sadio), Honneth tem de assumir, mais uma vez, como Weber e Habermas, que a condição pré-moderna de uma moral arcaica não só imbricaria de modo férreo essas três esferas do reconhecimento e lhes impediria a descentração, como também e, por consequência, não geraria esse nível pós-tradicional que é próprio somente à modernidade, que somente é gerado como modernização enquanto europeização. Ele ressalta: 
Por conseguinte, o quadro interpretativo geral de que dependemos descreve $o$ processo de formação moral através do qual se desdobrou o potencial normativo do reconhecimento recíproco ao longo de uma sequência idealizada de lutas. Nas distinçóes teóricas que puderam ser obtidas das reflexóes de Hegel e Mead, uma semelhante construção encontra seu ponto de partida sistemático. De acordo com isso, são as três formas de reconhecimento do amor, do direito e da estima que criam primeiramente, tomadas em conjunto, as condiçóes sociais sob as quais os sujeitos humanos podem chegar a uma atitude positiva para com eles mesmos; pois só graças à acumulação gradativa de autoconfiança, autorrespeito e autoestima, como garante sucessivamente a experiência das três formas de reconhecimento, uma pessoa é capaz de se conceber de modo irrestrito como um ser autônomo $e$ individuado e de se identificar com seus objetivos e desejos. Ora, essa tripartição se deve a uma retroprojeção teórica de diferenciações que só puderam ser obtidas em sociedades modernas sobre um estado inicial aceito hipoteticamente; pois em nossa análise vimos que a relação jurídica só pôde se desligar do quadro ético da estima social no momento em que é submetida às pretensóes de uma moral pós-convencional. Nesse sentido, é natural adotar para a situação inicial do processo de formação a ser descrito uma forma de interação social em que aqueles três padróes de reconhecimento estavam ainda entrelaçados uns nos outros de maneira indistinta; a favor disso pode depor a existência de uma moral arcaica e interna de grupo, no interior da qual os aspectos da assistência náo estavam separados completamente nem dos direitos de membro da tribo nem de sua estima social. Por isso, o processo de aprendizado moral, que o quadro interpretativo em vista deve expor como modelo, teve de render duas idealizaçóes inteiramente distintas de uma vez só: provocar uma diferenciação dos diversos padrões de reconhecimento e, ao mesmo tempo, dentro das esferas de interaçáo assim criadas, liberar o respectivo potencial internamente inscrito. (HONNETH, 2003, p. 266-267, grifos nossos).

Novamente: o que sobraria ao outro da modernidade, como déficit universalista e modernizador, déficit universalista. porque déficit modernizador? Está irremediavelmente condenado ao passado, ao arcaísmo, ao primitivismo, à negatividade e, portanto, à extinção? Certamente que não, responde Habermas: há uma função e um caminho importantíssimos a esses outros da modernidade, os quais consistem em se modernizarem ou se europeizarem, para, então, dar razão à constituição, ao desenvolvimento e à evolução da modernidade-modernização europeia como universalismo pós-tradicional calcado na racionalização cultural-comunicativa. Pode parecer brincadeira, mas essa é exatamente a conclusão final da Teoria do agir comunicativo, de Habermas (2012b, p. 721, grifos do autor): 
O teste definitivo para uma teoria da racionalidade, por meio do qual a moderna compreensáo do mundo tenta se assegurar de sua universalidade, só poderia se realizar se as figuras opacas do pensamento mítico se iluminassem e as manifestaçóes bizarras de culturas estranhas se esclarecessem de tal modo que conseguíssemos entender náo somente os processos de aprendizagem que "nos" separam "delas", mas também o que desaprendemos no decorrer de nossos processos de aprendizagem.

Portanto, o passo definitivo para que a pressuposição da modernidademodernização europeia como universalismo pós-tradicional, por meio da racionalização cultural-comunicativa, como presente, contemporaneidade e caminho ao futuro, possa ser comprovada em toda a sua efetividade porque, para começo de conversa, é uma pressuposição calcada na cegueira histórico-sociológica, no dualismo-binarismo antropológico e, finalmente, na romantização normativa do racionalismo assumidos pelo discurso filosófico da modernidade - consiste na modernizaçáo-europeizaçáo dos outros da modernidade, porque, obviamente, se eles se modernizarem-europeizarem, eles se modernizarão-europeizarão! Uma conclusão no mínimo curiosa, talvez até ingênua, para uma perspectiva normativa que dificilmente esconde seu ranço, em termos de eurocentrismo-colonialismo-racismo. Uma vez modernizadoseuropeizados, os outros da modernidade - agora não mais como outros da modernidade, mas como europeus "de cor" - terão condiçóes de explicar o que foram e, visto que agora possuem uma base explicativo-legitimatória moderna, a modernidade europeia poderá entendê-los naquilo que ela já foi, mas superou.

\section{A MODERNIDADE COMO MONOCULTURA DE IDEIAS E COMO MUNDO ACACHAPANTE:}

\section{O PENSAMENTO INDÍGENA BRASILEIRO COMO CRÍTICA DA MODERNIDADE}

É com base na constatação desse não-lugar do indígena (e do negro), no discurso filosófico-sociológico-antropológico da modernidade-modernização ocidental e, no caso, pela sua (do indígena e do negro) enunciação por esse mesmo discurso, como negatividade, passado, arcaísmo, dogmatismo, em suma, condição-sujeito-valor pré-moderno, antimoderno e antimodernizante, enquanto perspectiva mítico-arcaica, que o pensamento indígena brasileiro emerge como consequência e justificação teórico-político-normativa da consolidação, a partir de meados da década de 1970, do Movimento Indígena brasileiro em termos de ativismo, militância e engajamento em torno à 
condição e à causa indígenas e sob a forma de crítica de nossa modernização periférica, calcada no racismo estrutural (cf. TUKANO, 2017, p. 15-26; KRENAK, 2015, p. 220; MUNDURUKU, 2012, p. 17-20). Nesse sentido, o primeiro ponto importante a ser consolidado pelo pensamento indígena brasileiro, em termos de crítica da modernidade, é exatamente a imbricação e a mútua dependência de modernização central e modernização periférica ou, por outras palavras, de eurocentrismo-colonialismo-racismo e/como fascismo, um argumento, aliás, que já vem sendo sustentado pela descolonização africana desde pelo menos a década de 1950, como podemos ver em Aimé Césaire, Kwame Nkrumah, Frantz Fanon, Patrice Lumumba, Albert Memmi, Léopold Sédar Senghor e Achille Mbembe (cf. CÉSAIRE, 1978, p. 14-33; NKRUMAH, 1966, p. 03-11, p. 66-77, p. 204-216; FANON, 1968, p. 2544; LUMUMBA, 1972, p. 53-142; MEMMI, 1967, p. 21-59; SENGHOR, 1959, p. 72; MBEMBE, 2014a, p. 10-64; MBEMBE, 2014b, p. 19-66; WERÁ JECUPÉ, 2002a, p. 45-59).

A modernidade-modernização ocidental é, concomitantemente, um movimento expansivo globalizante que tem seu núcleo no eurocentrismocolonialismo-racismo e/como fascismo (de dentro da modernidade para fora, relativamente aos outros da modernidade) e, ao mesmo tempo, como argumenta Aimé Césaire, possui um núcleo regressivo totalizante que vem de fora (dessa experiência de instrumentalização e etnocídio-genocídio planificados contra indígenas e negros, por sociedades modernas) para dentro (racismo nas colônias, totalitarismo nas metrópoles e entre metrópoles). ${ }^{5}$ Em

\footnotetext{
5 Ele afirma: "Seria preciso estudar, primeiro, como a colonizaçáo se esmera em descivilizar o colonizador, em embrutecê-lo, na verdadeira acepção da palavra, em degradá-lo, em despertá-lo para os instintos ocultos, para a cobiça, para a violência, para o ódio racial, para o relativismo moral, e mostrar que, sempre que há uma cabeça degolada e um olho esvaziado no Vietname e que em França se aceita, uma rapariguinha violada e que em França se aceita, um Malgaxe supliciado e que em França se aceita, há uma aquisiçáo de civilização que pesa com o seu peso morto, uma regressão universal que se opera, uma gangrena que se instala, um foco de infecção que se alastra e que, no fim de todos estes tratados violados, de todas estas mentiras propaladas, de todos estes prisioneiros manietados e 'interrogados', de todos estes patriotas torturados, no fim desta arrogância racial encorajada, desta jactância ostensiva, há o veneno instilado nas veias da Europa e o progresso lento, mas seguro, do asselvajamento do continente [...]. E, entâo, em um belo dia, a burguesia é despertada por um ricochete: as gestapos afadigam-se, as prisóes enchem-se, os torcionários inventam, requintam, discutem em torno dos cavaletes [...]. As pessoas espantam-se, indignam-se. Dizem: 'Como é curioso! Ora! É o nazismo, isso passa!'. E aguardam, e esperam; e calam em si próprias a verdade - que é uma barbárie, mas a barbárie suprema, a que coroa, a que resume a quotidianidade das barbáries; que é o nazismo, sim, mas que, antes de serem as suas vítimas, foram os cúmplices; que o toleraram, esse mesmo nazismo, antes de o sofrer, absolveram-no, fecharam-lhe os olhos, legitimaram-no, porque até aí só se tinha aplicado a povos não europeus; que o cultivaram, são responsáveis por ele, e que ele brota, rompe, goteja, antes de submergir nas suas águas avermelhadas de todas as fissuras da civilização ocidental e cristã [...]. Sim,
} 
suma: a chave analítica e a base normativa para a reconstrução do processo de modernidade-modernizaçáo, enquanto universalismo pós-tradicional ou sistema-mundo global, é dada pela tríade eurocentrismo-colonialismoracismo e/como fascismo e, aqui, o racismo estrutural explicaria exatamente essa compreensão e separação dualistas-binárias entre modernidade e o outro da modernidade, com a consequente separação, autonomização $e$ sobreposição da primeira em relação ao segundo.

Nessa perspectiva, a colonização, amparada no racismo estrutural e materializada institucionalmente como fascismo planificado, constitui-se em um processo de produção de menoridades político-normativo-culturais racialmente estruturadas, as quais são concomitantemente (a) concebidas como sujeitos do passado, como negatividade normativo-moral e como condiçáo pré-moderna, antimoderna e antimodernizante, incapaz de modernização e inapta para a civilização e necessitando, por isso, de tutoria, seja moralepistêmica, seja jurídico-política, seja mesmo em termos de chicote e cabresto; (b) transformadas em instrumentalidade econômica, na medida em que, como sujeitos e condição pré-modernos e desde a separação entre culturacivilização (como modernidade) versus natureza-animalidade viabilizada pelo racismo, se aproximam da mera animalidade, com corpo humano, porém, instinto selvagem, de modo que sua escravização, seu estupro, a expulsão dos seus territórios, a deslegitimação de suas formas de ser e estar no mundo e, finalmente, seu etnocídio-genocídio não causariam nenhuma comoção moral, nenhuma sensibilidade moral. Conforme já assinalava Frantz Fanon, no contexto do eurocentrismo-colonialismo-racismo e/como fascismo, não há reconhecimento recíproco e, portanto, universalidade dos direitos, segurança e isonomia jurídicas, garantias fundamentais e mediaçóes institucionais, mas apenas a violência direta, um instrumentalismo absoluto e a guerra etnocidagenocida de eliminação (FANON, 2008, p. 26-106).

O negro e o indígena foram produzidos pela colonização e desde a base antropológico-normativo-epistêmica do racismo estrutural, e seu etnocídiogenocídio representou a primeira e mais pungente experiência de fascismo

valeria a pena estudar clinicamente, no pormenor, os itinerários de Hitler e do Hitlerismo e revelar ao burguês muito distinto, muito humanista, muito cristão do século XX, que traz em si um Hitler que se ignora, que Hitler vive nele, que Hitler é o seu demônio, que se o vitupera é por falta de lógica, que, no fundo, o que não perdoa a Hitler não é o crime em si, o crime contra o homem, não é a humilhação do homem em si, é o crime contra o homem branco, a humilhação do homem branco e o ter aplicado à Europa processos colonialistas a que até aqui só os árabes da Argélia, os 'coolies' da Índia e os negros da África estavam subordinados.” (CÉSAIRE, 1978, p. 18; os grifos sâo do autor). 
institucionalizado e planificado - o qual, no contexto da África, sobreviveu até pelo menos a década de 1970, tendo seu ocaso com a derrocada do regime do apartheid na África do Sul, em 1992. Enquanto menoridades político-culturais racialmente sustentadas e reproduzidas, naturalizar-se-ia e despolitizar-se-ia essa condição de violência simbólico-material própria ao colonialismo e mesmo o processo fascista de etnocídio-genocídio, inclusive com a justificaçáo da tutoria dos indígenas e dos negros pelos brancos e a consequente privatização e invisibilização daqueles, já que os indígenas (a) seriam vistos como meros instrumentos e pura animalidade, direcionados à exploração e ao abate, e (b), como incapazes de responsabilidade, de fala e de postura autônomas, no âmbito da esfera pública e, como sujeitos políticoculturais na maturidade de sua condição de maioridade jurídica, seriam invisibilizados, silenciados e privatizados, a ponto de serem escondidos dos olhares, dos ouvidos e das bocas do público.

A correlação de instrumentalização antropológica e de silenciamento, invisibilização e privatização políticos dos sujeitos indígenas, no contexto do eurocentrismo-colonialismo-racismo e/como fascismo, possibilitou, por conseguinte, (a) o roubo de suas terras, a deslegitimação e o apagamento de suas formas de ser e estar no mundo, seu estupro e a sua escravizaçáo; (b) a sua tutoria pelo senhor branco, civilizado, racional (a qual, no caso dos indígenas brasileiros, só foi eliminada com a Constituição Federal de 1988, que derrogou, no assim chamado Capítulo dos Índios, a maioridade relativa até então atribuída e imposta aos nossos povos-sujeitos indígenas), que viabilizava tanto a unidimensionalização e a massificação da história nacional, de nossos valores, datas e símbolos mais básicos, em torno a uma noção idílica de descoberta e de desenvolvimento colonial que culminava na democracia racial e, portanto, na eliminação do racismo estrutural e na consolidação da grande família Brasil, totalmente miscigenada, fundida, sem contradiçóes, diferenciaçôes e cisôes internas, de unidade, amálgama e ordem absolutos, e hierarquicamente ordenada, quanto sua invisibilização, seu silenciamento e seu privatismo político-culturais, com a consequente deslegitimação do racismo estrutural e de sua condição efetivamente atual, em termos de nossa modernização conservadora, como seu substrato mais central; e (c) a intensificação dos processos de etnocídio e genocídio planificados, concomitantes aos processos de desterritorialização e de destruição de suas culturas, de suas histórias, de suas formas de ser e estar no mundo. 
Por isso mesmo, o pensamento indígena brasileiro e o Movimento Indígena brasileiro, ao qual aquele está atrelado, desde o início viram no ativismo, na militância e no engajamento públicos, políticos e culturais direcionados à condição e à causa indígenas, e desde uma voz-práxis direta, autoral, autobiográfica, testemunhal, experiencial e mnemônica fundamentada na promoção da sua alteridade (e com base nela como estrutura epistêmicopolítica) e na denúncia da marginalização, da exclusão e da violência vividas e sofridas como minorias político-culturais produzidas pelo colonialismoracismo, a única possibilidade de resistência, de reflexivização e de criticismo em relação a esses processos de etnocídio-genocídio ainda em curso contemporaneamente. No caso, pois, buscaram superar o silenciamento, a invisibilização e o privatismo aos quais estavam submetidos, por meio da constituição de um lugar de fala político e politizante, carnal e vinculado, o qual tinha na descolonização e na descatequizaçáo da cultura-consciência o seu núcleo estruturante.

Ora, para esse lugar de fala descolonizador e descatequisador, crítico do racismo e altamente político e politizante, a primeira tarefa fundamental consistiu em desconstruir os estereótipos produzidos sobre os indígenas pelo eurocentrismo-colonialismo-racismo, e o primeiro e mais fundamental desses estereótipos estava em que os índios não existem, em que os índios não são índios. Assinala Ailton Krenak sobre sua militância em torno ao Movimento Indígena brasileiro e em termos desse lugar de fala descolonizador, crítico do eurocentrismo-colonialismo-racismo:

E o outro desconforto era me identificar como índio, porque índio é um erro de português, plagiando o Oswald, que disse que, quando o português chegou no Brasil, estava uma baita chuva, aí ele vestiu o índio, mas, se estivesse num dia de sol, o índio teria vestido o português, e estaria todo mundo andando pelado por aí. Isso continua valendo até hoje, e eu atualizei dizendo que o índio é um equívoco do português, náo um erro, porque o português saiu para ir para a Î́ndia. Mas ele perdeu a pista e veio bater aqui nas terras tropicais de Pindorama, viu os transeuntes da praia e acabou carimbando de índios. Aquele carimbo errado, equivoco, ficou valendo para o resto das nossas relaçôes até hoje, e a resposta para uma pergunta tấo direta $\mathrm{e}$ simples poderia ser tão direta e simples quanto. Quando foi que eu atinei que eu tinha de fazer essas coisas que ando fazendo nos últimos 50 anos da minha vida, que é quase que repetir o mesmo mantra, dizendo para esse outro: "ô, cara, essa figura que você está vendo no espelho não sou eu não, é você, esse espelhinho que você está me vendendo não sou eu, isso é um equívoco!"? E saí do sentimento para a prática na pista dos meus parentes mais velhos do que eu, que estavam sendo despachados da zona rural para 
as periferias miseráveis do Brasil, o que acontece em qualquer canto, no Norte, no Sul, em qualquer lugar. (KRENAK, 2015, p. 239, grifos nossos. Cf., ainda: MUNDURUKU, 2016, p. 21-52; 2018, p. 27-28; WERÁ, 2017, p. 101-107).

$\mathrm{O}$ índio, portanto, enquanto sujeito ao mesmo tempo racializado e demarcado pelo dualismo-binarismo civilizaçáo versus animalidade, cultura versus natureza e modernidade versus tradicionalismo, é uma invenção pura e simples do e pelo eurocentrismo-colonialismo-racismo e/como fascismo; ele não existe, enquanto entidade independente desse mesmo eurocentrismo-colonialismo-racismo e/como fascismo e, na verdade, ele não existe, independentemente da modernidade e da expansão universalizante da modernização ocidental como sistema-mundo calcado no colonialismo e no racismo, produtor e reprodutor de menoridades político-culturais e de instrumentalização econômica. É por meio da modernidade que aquele aparece na história ocidental como negatividade e condição-sujeito pré-moderno que respaldam a função tutorial, a vocação civilizatória e a dinâmica missionária, messiânica e expansiva da, como e pela modernidade; e, por outro lado - daí seu enorme potencial político, como, de resto, é o caso de todas as minorias político-culturais produzidas no contexto do dualismo-binarismo moderno e, em particular, do racismo estrutural - a viabilização e a vinculação públicopolíticas do e pelo lugar de fala indígena como voz-práxis política e politizante, desde um eu-nós estético-político carnal e militante, possibilitam exatamente a construção de histórias e a afirmação de sujeitos, valores, práticas e símbolos alternativos em relação ao discurso filosófico-sociológico da modernidademodernização ocidental.

Mais uma vez, produzidas política e normativamente como negatividade e instrumentalidade, através do racismo estrutural e submetidas a um processo de escravização, de invisibilização e de etnocídio-genocídio, em termos de fascismo institucionalizado e planificado, essas minorias políticoculturais, na medida em que se enraízam e se vinculam na esfera pública, desnaturalizam e politizam radicalmente a história nacional e o sentido contraditório da modernidade-modernização ocidental e, assim, visibilizam e explicitam o racismo estrutural que tem sido escondido e negado por nossa modernização conservadora - como consequência, também visibilizam e pungenciam a continuidade dos processos de etnocídio-genocídio contra essas mesmas minorias político-culturais. Sobre isso, Ailton Krenak (2015, p. 8485) afirma: 
Acho que você conhece a história das potências que colonizaram outras regióes do mundo e que tratam os nativos como cidadáos de segunda ou de terceira categoria. Se você observar, a Inglaterra e a França mantinham até recentemente colônias na África e na Ásia, onde os nativos tinham o status aproximado da mula ou do cavalo. Aqui, no Brasil, os índios continuam tendo um status parecido com o de animais silvestres. Nós somos objetos da atenção do Estado enquanto seres que precisam ser preservados como fauna. Também temos a atenção do Estado como pessoas e indivíduos que precisam ser vigiados para que não entrem em um processo de contestação do poder do Estado, de contestação da ordem estabelecida e de questionamento dos crimes que foram praticados contra o nosso povo. Nós somos a memória viva e um testemunho sempre explícito da história recente da ocupaçáo desta região do mundo. Cada um dos nossos meninos sabe como foi que os brancos se tornaram senhores desta terra e quando e como nós deixamos de ser os donos. (cf., ainda: MUNDURUKU, 2012, p. 15-39; POTIGUARA, 2019, p. 99-116).

Como memória viva e testemunho atual e/porque autobiográfico relativamente à expansão da modernidade-modernização ocidental, em termos de eurocentrismo-colonialismo-racismo e/como fascismo, os povos indígenas (e negros) levam não apenas à visibilização de uma faceta da modernidade, a qual é grandemente silenciada, negada e deslegitimada por esta (o eurocentrismo-colonialismo-racismo e/como fascismo), como também permitem a construção de uma nova versão da colonização que rompe, seja com a ideia de uma expansão linear da modernidade-modernização ocidental para o futuro e como universalismo pós-tradicional reto e direto, como que impoluto, seja com a noçáo idílica de uma civilizaçáo nos trópicos e de um processo de colonização humanizadora, que, pela miscigenação, supera o racismo estrutural e elimina de vez, tanto os processos de produção-reprodução planificada de menoridades político-culturais como negatividade quanto seu consequente etnocídio-genocídio, fundando a nossa grande família Brasil fundida, plenamente integrada e totalmente indiferenciada.

Efetivamente, o seu lugar de fala, enquanto voz-práxis estéticopolítica, é o que demarca e dinamiza, no caso das minorias político-culturais, essa sua enorme potência reflexiva, crítica e político-politizante enquanto descolonização e descatequização, enquanto visibilização, denúncia e combate em relação à expansão (e regressão) totalizante da modernidade-modernização ocidental como eurocentrismo-colonialismo-racismo e/como fascismo. Notese que é um lugar de fala político e politizante, carnal e vinculado, o qual, 
enquanto fiç̧ão estético-política (e não como pertença identitária essencialista e naturalizada, e muito menos como núcleo racial-racializado, ao contrário do racismo moderno-colonial), bebe na correlação (a) de singularidade étnicoantropológica, que funda uma perspectiva epistêmico-normativo-política calcada na afirmação de sua pertença como aguilhão de autoafirmação, de autocompreensão e de ativismo social, político, cultural e institucional (pensamento indígena, pensamento negro, pensamento feminista, pensamento queer etc.), bem como (b) de experiências autobiográficas de exclusão, marginalizaçáo e violência etnocida-genocida como minorias político-culturais.

É nesse sentido que Ailton Krenak enfatiza, acima, que os povos indígenas são memória viva e testemunho explícito da evolução totalizante da modernidade e de sua manifestação como eurocentrismo-colonialismo-racismo e/como fascismo, porque foram produzidos por ela, porque são o resultado dela - e resultado no duplo sentido, como objetos, como negatividade, $e$ como o que sobrou após tantos momentos de extermínio etnocida-genocida, incluindo-se, aqui, a eliminação simbólico-normativa (ou a deslegitimaçáo) das suas formas de ser e estar no mundo. Por conseguinte, no relato-práxis autoral, direito, autobiográfico das e pelas minorias político-culturais, dos e pelos povos indígenas, uma outra história da modernização emerge, a saber, como colonialismo calcado no racismo, como guerra de colonização. Mais uma vez é Krenak (2015, p. 84) quem nos fala:

Acho que a maioria das pessoas tem dificuldade de nos considerar remanescentes de uma guerra de ocupaçáo. Quando os seus parentes vieram para cá, involuntariamente se instalaram como forças de ocupação da minha terra. Acredito que a grande maioria veio para cá sem saber o que estava fazendo. Os que vieram sabendo o que estavam fazendo e os que vieram sem saber estavam realizando a ocupação de nossos territórios. Hoje, se a minha tribo está reduzida a quase uma centena de indivíduos, sendo que, no começo do século, nós éramos mais de cinco mil pessoas, e se o nosso território atual é uma reserva mineral de quatro mil hectares, isso tem de ser compreendido como parte de minha história, muito mais que uma cédula de identidade. A minha história é a experiência coletiva do meu povo.

A passagem refere-se à discussão por Ailton Krenak quanto à questão da maioridade relativa, que culminou com o Capítulo dos Índios, na Constituição Federal de 1988, mas ela traz, para o que nos interessa nesse texto, exatamente a ideia de uma outra compreensão da modernidade-modernização ocidental 
e, por consequência, de uma outra versão da história da colonização. De um movimento desbravador, que funda uma civilização nos trópicos, e de uma civilização na verdade muito especial e singular, porque democracia racial enquanto miscigenação, fusão, amálgama, unidade e indiferenciação plenos entre as três matrizes raciais fundadoras (miscigenação que, ao fundar o híbrido brasileiro, elimina o racismo estrutural e inicia um novo capítulo de e para nossa sociedade, plenamente universalista por causa dessa miscigenação), como vemos no ideário romântico brasileiro, não por acaso retomado pela extrema-direita hoje hegemônica, passa-se a dar, com a voz-práxis direta, autobiográfica, pública e politizada dos e pelos indígenas, o verdadeiro "nome aos bois": guerra de colonização, processo planificado de produção e de extermínio de menoridades político-culturais racialmente fundadas - ou seja, colonizaçáo como racismo estrutural e fascismo institucional, cuja finalidade, inscrita nessa produção racializada de menoridades político-culturais, consiste na dinamização de um processo de etnocídio-genocídio institucionalmente referendado e realizado.

Como consequência dessa história e dessa compreensão alternativas relativamente à modernização/colonização, temos também a emergência e a apresentação de um papel sociopolítico e epistêmico-normativo e de um lugar e de um sentido alternativos aos, pelos e dos povos indígenas, no contexto da modernização e frente ao eurocentrismo-colonialismo-racismo e/como fascismo, ou seja, o de, através de sua resistência, de seu diálogo e de seu acordo permanente com os colonizadores, tentar educá-los para a alteridade e pelo reconhecimento recíproco, isto é, nas palavras mais uma vez de Ailton Krenak, de pacificar o branco relativamente à sua condição fundamentalista, dogmática, fanaticista, totalitária, racista e, como síntese de tudo isso, fascista em relação à diversidade humana (observe-se a inversão da lógica do discurso filosóficosociológico-antropológico da modernidade-modernização ocidental!):

Então, eu acredito que esses 500 anos de contato com os brancos, em que o nosso povo tentou pacificar o branco, tentou amansar o branco, tentou dizer para o branco que é possível viver de uma outra maneira, foram anos de muita dificuldade, de muita morte. Eu não saberia contar quantas pessoas indígenas foram mortas nesses 500 anos. Nós éramos aproximadamente 10 milhôes de pessoas que vivíamos aqui neste lugar que é a costa do Atlântico até a parte mais central do que eles chamam hoje de Brasil. Nisto que eles chamam de costa brasileira havia dezenas e dezenas de aldeias. Nós éramos dez milhôes quando chegaram apenas três canoas com os brancos dentro delas. Hoje somos 220 mil pessoas e os brancos são 130 milhóes. O que a gente pode concluir de uma história dessas? Foi bom para o nosso povo? (KRENAK, 2015, p. 157). 
Note-se, portanto, que temos, conforme já chamamos a atenção acima, uma inversão da lógica do discurso filosófico-sociológico da modernidade, a saber, de que é o sujeito aparentemente pré-moderno, antimoderno e antimodernizante, esse sujeito produzido pelo discurso filosófico-sociológico moderno como negatividade, como antítese da modernidade, que se revela como o verdadeiro núcleo reflexivizador, crítico e corretivo da modernidade. E, no caso do eurocentrismo-colonialismo-racismo e/como fascismo, são os povos indígenas que buscaram e buscam educar os "brancos" quanto à sua tendência autoritária, totalizante e simplificadora, que os leva ao fascismo etnocida-genocida amparado no racismo e dependente de dualismos, maniqueísmos e binarismos espúrios.

Estes, na verdade, ao criarem uma cisão intransponível, ao estabelecerem um purismo e uma endogenia cegos e irreflexivos e, finalmente, ao estratificarem o gênero humano em graus hierárquicos de evolução societal-culturalcognitiva que justificam não apenas a condição presente, contemporânea e a abertura para o futuro da, pela e como Europa, mas também a conceituaçáo dos outros da modernidade como passado, negatividade e irreflexividade, permitiram exatamente a degeneração da modernidade como eurocentrismocolonialismo-racismo-fascismo, da qual ela não consegue se livrar facilmente por causa de sua cegueira histórico-sociológica, de seu dualismo-binarismo antropológico e de sua romantização normativa do racionalismo. Por isso, caberá aos povos indígenas e negros chamarem a atenção, por meio de seu lugar de fala, enquanto voz-práxis direta e autobiográfica de caráter descolonizador e descatequisador, como quer Ailton Krenak, para o fato de que o Ocidente é uma "[...] monocultura de ideias" (KRENAK, 2017, p. 109).

Como procuramos desenvolver, nas primeiras partes deste texto, as ideias (a) de uma separação estrita e purista da modernidade europeia, em relação aos outros da modernidade, (b) de uma autoatribuição da modernidade como universalismo pós-tradicional e sua conceituação genérica e simplificadora de todos os outros da modernidade, como tradicionalismo em geral, (c) de uma endogenia, de uma autorreferencialidade e de uma autossubsistência absolutas da modernidade-modernização ocidental, como correlação, separação e tensão-contradição entre modernidade cultural e modernização econômicosocial (com o silenciamento sobre e o apagamento do colonialismo pelas teorias da modernidade), (d) de correlação de modernidade, como presente, contemporaneidade e de abertura para o futuro, e do outro da modernidade e/como passado, negatividade, déficit de universalidade e déficit modernizador; 
(e) de modernidade, desnaturalização, politização, diferenciação, autocrítica, autorreflexividade, autocorreção e autotransformação, e de outro da modernidade enquanto naturalização e apoliticidade-despolitização, dogmatismo, autoritarismo e fanatismo, bem como (f) a estratificação do gênero humano em etapas evolutivas escalonadas, na qual a Europa aparece como presente e apogeu do gênero humano, enquanto universalismo póstradicional, e os outros da modernidade são situados no passado e como tradicionalismo em geral, particularista, contextualista, não-racional e incapaz de racionalização social, esses pressupostos de fundo do e pelo discurso filosófico-sociológico da modernidade tornam o paradigma normativo da modernidade simplesmente incapaz, quer de reconhecer alteridades qua alteridades, quer de relacionar-se horizontalmente com elas e, finalmente, quer de reconhecer esse seu viés eurocêntrico-colonialista-racista-fascista.

Dessa forma, Ailton Krenak pode complementar essa sua crítica da modernidade-modernizaçáo ocidental como uma monocultura de ideias, fechada à alteridade e, de modo mais estrito, produtora de menoridades político-culturais racializadas, como negatividade e condição-sujeito prémoderno, o qual, por isso mesmo, pode ser tutoriado e, se for o caso, destruído em nome dos - e com base nos - valores universais da civilização ocidental. Krenak (2017, p. 115) assevera:

O que já indica, de certa maneira, a pouca valorização do pensamento ameríndio, do pensamento autóctone, ante a visão abrangente que os civilizados têm do seu mundo. Um mundo em si. Um mundo acachapante, que não precisa de colaboração. E que não abre espaço para que se ofereça uma crítica ou para apresentar uma crítica a essa visão tão completa do que é a civilização e do que são as cidades. (Cf., ainda: ESBELL, 2018, p. 25100; TUKANO, 2017, p. 39-40; MUNDURUKU, 2016, p. 165-204).

De fato, conforme estamos tematizando neste texto, a correlação de cegueira histórico-sociológica, de dualismo-binarismo antropológico e de romantização normativa do racionalismo ocidental, pelo discurso filosóficosociológico da modernidade, tem por consequência não apenas o sustento dessa endogenia, dessa internalidade, desse purismo, dessa autorreferencialidade e dessa autossubsistência absolutos da modernidade, como europeizaçáo por si mesma e desde dentro de si mesma, mas também, segundo vimos, em Habermas e em Honneth, a deslegitimação do não moderno como prémoderno, como condição-sujeito antimoderno e antimodernizante, incapaz de autorreflexividade, de autocrítica, de autocorreçáo e de autotransformação 
internas (e, portanto, incapaz de modernização-europeização) e, assim, inapto para uma crítica da modernidade-modernização ocidental, a qual somente pode ser feita desde dentro da modernidade e a partir da assunção do paradigma normativo da modernidade (racionalização cultural, procedimentalismo imparcial, impessoal, neutro e formal e desnaturalização e politização da sociedade-cultura-consciência, em função da separação de natureza, sociedadecultura e subjetividade).

No paradigma normativo da modernidade e por causa desses pressupostos, a crítica da modernidade só pode ser realizada desde dentro dela e, dado que a modernidade é universalista, em nível pós-tradicional e, pois, a verdadeira gênese, base legitimadora e guardiã normativo-material dos direitos humanos e da democracia, legitima-se também o fato de que somente com a universalidade europeia e por ela (a qual é correlacionada pela própria Europa à universalidade do gênero humano), e desde a modernização e através de seu paradigma normativo, se pode enquadrar as demais sociedades-culturas, oferecendo-se um guarda-chuva normativo universalista capaz de reflexivizar, criticar, justificar e transformar aos outros da modernidade, enquanto particularidade. Indígenas e negros, como condiçóes-sujeitos pré-modernos, antimodernos e antimodernizantes, não poderiam criticar-se e reflexivizarse internamente, criticar e reflexivizar a modernidade e, finalmente, criticar, reflexivizar e fundamentar uma concepção universalista de direitos humanos com capacidade de enquadramento e orientação das sociedades-culturas particulares.

É por isso que a crítica de Ailton Krenak, acima destacada, chama a atenção para esse caráter autossuficiente e fechado da modernidade, em relação ao outro da modernidade, correlato à autoatribuição de si por si mesma, enquanto universalidade, e à sua negativação desses outros da modernidade, em termos de uma postura no mínimo de colonialidade cultural (QUIJANO, 1992, p. 11-20) e, no limite, de eurocentrismo-colonialismo-racismofascismo. Nesse sentido, inclusive, a busca do e pelo pensamento indígena por pacificar, educar, sensibilizar e reorientar a modernidade se dá - e essa é outra característica importante do pensamento indígena brasileiro ou mesmo da descolonização africana e da filosofia latino-americana - a partir da utilização do próprio arcabouço epistêmico-normativo-político-moral (ou mesmo antropológico-ontológico), o que significa, no caso dos povos indígenas, que suas "histórias da humanidade" (TUKANO, 2017, p. 15), as quais não podem ser confundidas com a noção moderna de mito (mito enquanto 
negatividade das formas de ser e estar no mundo náo europeias, ao passo que a modernidade possui formas de ser e estar no mundo com o status de ciência, diga-se de passagem), dinamizadas via xamanismo, servem como arcabouço e núcleo axiológico do diálogo e da crítica relativamente à modernidade.

Vejamos, nessa linha, o diálogo com a modernidade, desde a própria base normativa indígena, proposto por Davi Kopenawa, xamã yanomami de Roraima:

Os brancos não pensam muito adiante no futuro. Sempre estão preocupados demais com as coisas do momento. É por isso que eu gostaria que eles ouvissem minhas palavras através dos desenhos que você fez delas; para que penetrem em suas mentes. Gostaria que, após tê-las compreendido, dissessem a si mesmos: "Os Yanomami são gente diferente de nós e, no entanto, suas palavras são retas e claras. Agora entendemos o que eles pensam. São palavras verdadeiras! A floresta deles é bela e silenciosa. Eles ali foram criados e vivem sem preocupação desde o primeiro tempo. $\mathrm{O}$ pensamento deles segue caminhos outros que o da mercadoria. Eles querem viver como lhes apraz. Seu costume é diferente. Não têm peles de imagens, mas conhecem os espíritos xapiri e seus cantos. Querem defender sua terra porque desejam continuar vivendo nela como antigamente. Assim seja! Se eles não a protegerem, seus filhos não terão lugar para viver felizes. Vão pensar que a seus pais de fato faltava inteligência, já que só terão deixado para eles uma terra nua e queimada, impregnada de fumaças de epidemia e cortada por rios de águas sujas!".

Gostaria que os brancos parassem de pensar que a nossa floresta é morta e que ela foi posta lá à toa. Quero fazê-los escutar a voz dos xapiri, que ali brincam sem parar, dançando sobre seus espelhos resplandecentes. Quem sabe assim eles queiram defendê-la conosco? Quero também que os filhos e filhas deles entendam nossas palavras e fiquem amigos dos nossos, para que não cresçam na ignorância. Porque, se a floresta for completamente devastada, nunca mais vai nascer outra. Descendo desses habitantes da terra das nascentes dos rios, filhos e genros de Omama. São as palavras dele, e as dos xapiri, surgidas no tempo do sonho, que desejo oferecer aqui aos brancos. Nossos antepassados as possuíam desde o primeiro tempo. Depois, quando chegou a minha vez de me tornar xamá, a imagem de Omama as colocou em meu peito. Desde então, meu pensamento vai de uma para outra, em todas as direçóes; elas aumentam em mim sem fim. Assim é. Meu único professor foi Omama. São as palavras dele, vindas dos meus maiores, que me tornaram mais inteligente. Minhas palavras não têm outra origem. As dos brancos são bem diferentes. Eles são engenhosos, é verdade, mas carecem muito de sabedoria. (KOPENAWA; ALBERT, 2015, p. 64-65. Ver, ainda: WERÁ JECUPÉ, 2002b, p. 19-41). 
Note-se, nessa passagem, uma crítica à modernidade pelo outro da modernidade, por esse outro que ela criou como negatividade, como déficit de universalidade, como déficit de modernidade e, por isso mesmo, como condição-sujeito passado e do passado. Observe-se, ademais, a crítica da modernidade desde o xamanismo, isto é, desde as formas de ser e estar no mundo não europeias, em que as minorias político-culturais se utilizam de seu arcabouço antropológico-ontológico e de sua base epistêmico-políticonormativa, para enquadrar à modernidade ocidental e à sua expansão universalizante como instrumentalização.

Note-se, enfim, e com isso vamos entrando no momento derradeiro desse artigo, na gradativa explicitação e na forte ênfase em outra base paradigmática para o universalismo, a qual é oferecida pelos povos indígenas (e pelos povos negros), como contraponto ao universalismo deficitário da modernidade-modernização europeia, com o que temos mais uma inversão da lógica do paradigma normativo da modernidade.

Se este concebe o - e se afirma como o - autêntico universalismo epistemológico-moral, enquanto perspectiva pós-tradicional calcada na racionalização sociocultural e dinamizada pela correlação de separação entre natureza, sociedade-cultura e subjetividade e de procedimentalismo imparcial, impessoal, neutro e formal, com a negativação dos outros da modernidade como tradicionalismo em geral, pré-moderno, antimoderno e antimodernizante, e como passado evolutivo do e ao gênero humano; e se ele dá um passo adiante, colocando-se, por causa de sua autotematização como ápice, condição presente e contemporânea e abertura ao futuro do gênero humano, enquanto guarda-chuva normativo de todas as sociedades-culturas, ele e somente ele, os povos indígenas, ao revelarem esse déficit de reflexividade e, portanto, esse déficit de universalidade da e pela modernidade devido à sua cegueira histórico-sociológica, ao dualismo-binarismo antropológico e à romantização normativa do racionalismo ocidental, oferecem-lhe um universalismo horizontalizado, anticolonial, antifascista, antitotalitário, não fundamentalista e antirracista, um efetivo universalismo não etnocêntrico e não egocêntrico, a saber, a Mãe Terra ou Pachamama:

Aqui de onde estamos, dentro do coração, somos guardiães da Mãe Terra. Que já não suporta tanta ignorância. Sua pele haverá de se arrepiar e sacudir o mal, seu ventre haverá de vomitar. E nós estamos aqui somente pelo Mboraí, o Grande Amor, dispostos a ajudar esses que se dizem civilizados. Escreva. É chegado o tempo. Os grandes tupis retornam à Terra. As velhas almas, as palavras primeiras, retornam à Terra. As velhas almas, as 
palavras primeiras, retornam para semear esse chão da antiga sabedoria que os tempos guardaram na secreta memória da Terra. A sabedoria desses povos primeiros, os que se adornam com o arco-íris, é necessária para a sobrevivência da Mãe. Da grande provedora. Embora semente, és uma alma velha; espalhe nossas palavras, assim como em outros cantos parentes da antiga linguagem estáo semeando, pela luta, o ato da vida. Escreva o que já está escrito, é chegado o tempo. [...] Gostaria de lembrar uma coisa a todos. Somos tecidos da terra, do fogo, da água e do ar. E nada serviria à mais avançada inteligência se a Grande Mãe não ofertasse o seu próprio corpo, suas próprias veias cristalinas, seu próprio ventre, para tornar possível existir desde o mais simples cocar à mais complexa arma atômica. Somos tecidos do tecido que tece a própria Máe e tudo o que criamos vem dessa mesma trama. Essa trama é uma lei ancestral, é uma lei imemorial. Os povos indígenas conhecem essa lei. (WERÁ JECUPÉ, 2002a, p. 93-112. Cf., ainda: KRENAK, 2019, p. 14-40; KOPENAWA; ALBERT, 2015, p. 364-372).

Como lei ancestral e imemorial, Pachamama imbrica o ontem, o hoje e o amanhã. Imbrica-nos e equaliza-nos, independentemente de nosso lugar geográfico, antropológico e epistêmico. E, o que é melhor, imbrica-nos sem hierarquizar, sem dualismos, sem maniqueísmos, sem binarismos. Imbricanos pela gratuidade da vida, e de uma vida completa, ou seja, universalismo anticolonial, antitotalitário, não fundamentalista e antirracista, aberto, equânime, pluralizado, diferenciado e, ainda assim (e por causa disso), comum, integrado.

Danner, L. F.; DANNER, F.; DORRICO, J. Pacifying the white man: a history of modernity told by indigenous peoples. Trans/Form/Açáo, Marília, v. 45, p. 379-414, 2022. Edição Especial.

\footnotetext{
Abstract: We develop the perspective of a criticism of modernity by Brazilian Indigenous thinking, from its denounce of modernization as an expansive and totalizing movement that has in the imbrication of eurocentrism-colonialism-racism and/as fascism its structuring and streamlining core. We will argue the proposal of an Indigenous thinking-praxis that offers and alternative explanation of modernity as war of colonization based on structural racism and having as consequence the institutional ethnocidegenocide against Indigenous and Blacks; and also that proposes an epistemic-political-normative role to Indigenous since their forms of being in the world, that is, to pacify the White man. Therefore, we have the inversion of a triple logic of modernity: the modernity as an endogenous, self-referential
} 
and self-subsistent perspective; the modernity as a lineal and direct expansive movement towards post-traditional universalism - and as post-traditional universalism - from cultural-communicative rationalization; and the modernity as the exclusive and necessary condition for the criticism of modernity, for the criticism of the others of modernity and for the basement of an universal notion of human rights, tasks that the others of modernity cannot generate or sustain.

Key-Words: Indigenous Thinking. Decolonization. Modernity. Colonialism. Racism. Fascism.

\section{REFERÊNCIAS}

CÉSAIRE, Aimé. Discurso sobre o Colonialismo. Lisboa: Sá da Costa, 1978.

ESBELL, Jaider. Jaider Esbell. Rio de Janeiro: Azougue, 2018 (Coleção Tembetá).

FANON, Frantz. Os Condenados da Terra. Rio de Janeiro: Paz e Terra, 1968.

FANON, Frantz. Pele Negra, Máscaras Brancas. Salvador: Editora da UFBA, 2008.

HABERMAS, Jürgen. O Discurso Filosófico da Modernidade: Doze Lições. São Paulo: Martins Fontes, 2002a.

HABERMAS, Jürgen. A Inclusáo do Outro: Estudos de Teoria Política. São Paulo: Loyola, 2002b.

HABERMAS, Jürgen. Teoria da Açáo Comunicativa: Racionalidade da Ação e Racionalização Social. São Paulo: Martins Fontes, 2012a.

HABERMAS, Jürgen. Teoria da Açáo Comunicativa: sobre a Crítica da Razão Funcionalista. São Paulo: Martins Fontes, 2012b.

HONNETH, Axel. Luta por Reconhecimento: a Gramática Moral dos Conflitos Sociais. São Paulo: Editora 34, 2003.

JECUPÉ, Kaká Werá. A Terra dos Mil Povos: História Indígena Brasileira Contada por um Índio. São Paulo: Peirópolis, 1998.

JECUPÉ, Kaká Werá. Oré Awé Roiru’a Ma: Todas as Vezes que Dissemos Adeus. São Paulo: TRIOM, 2002.

KOPENAWA, Davi; ALBERT, Bruce. A Queda do Céu: Palavras de Um Xamã Yanomami. São Paulo: Companhia das Letras, 2015.

KRENAK, Ailton. Encontros. Organização de Sergio Cohn. Rio de Janeiro: Azougue, 2015.

KRENAK, Ailton. Ailton Krenak. Rio de Janeiro: Azougue, 2017 (Coleção Tembetá).

KRENAK, Ailton. Ideias para Adiar o Fim do Mundo. São Paulo: Companhia das Letras, 2019.

LUMUMBA, Patrice. The Complete Speechs of Patrice Lumumba. Boston: Little, Brown and Company, 1972. 
MBEMBE, Achille. Crítica da Razáo Negra. Lisboa: Antígona, $2014 a$.

MBEMBE, Achille. Sair da Grande Noite: Ensaio sobre a África Descolonizada. Lisboa, Mulemba, 2014b.

MEMMI, Albert. Retrato do Colonizado precedido pelo Retrato do Colonizador. Rio de Janeiro: Civilização Brasileira, 1967.

MUNDURUKU, Daniel. A Escrita e a Autoria Fortalecendo a Identidade. In: RICARDO, Beto; RICARDO, Fany. Povos Indígenas do Brasil. São Paulo: Instituto Socioambiental, 2006. p. 200-202.

MUNDURUKU, Daniel. O Caráter Educativo do Movimento Indígena Brasileiro (1970-1990). São Paulo: Paulinas, 2012.

MUNDURUKU, Daniel. Memórias de Índio: Uma Quase Autobiografia. Porto Alegre: EDELBRA, 2016.

MUNDURUKU, Daniel. Daniel Munduruku. Rio de Janeiro: Azougue, 2018 (Coleção Tembetá).

NKRUMAH, Kwame. Neocolonialismo. México: Siglo XXI, 1966.

POTIGUARA, Eliane. Eliane Potiguara. Rio de Janeiro: Azougue , 2019 (Coleção Tembetá).

QUIJANO, Aníbal. Colonialidad y Modernidad/Racionalidade, Perú Indígena, v. 13, n. 29, p. 11-20, 1992.

SENGHOR, Léopold Sédar. On African Socialism. London: Pall Mall, 1959.

TERENA, Marcos. Cidadáos da Selva: a História Contada pelo Outro Lado. Rio de Janeiro: Gráfica JB, 1992.

TUKANO, Alvaro. Alvaro Tukano. Rio de Janeiro: Azougue, 2017 (Coleção Tembetá).

WEBER, Max. Ensayos sobre Sociología de la Religión (T. I). Madrid: Taurus, 1984.

WERÁ, Kaká. Kaká Werá. Rio de Janeiro: Azougue, 2017 (Coleção Tembetá).

Recebido: 15/8/2020

Aceito: $25 / 01 / 2021$ 
Danner, L. F.; DANNER, F.; DORRICO, J. 